\title{
Sowing dates and node emission in buckwheat cultivars
}

\section{Datas de semeadura e emissão de nós em cultivares de trigo mourisco}

\begin{abstract}
Alberto Cargnelutti Filho1*; Ismael Mario Márcio Neu²; Rafael Vieira Pezzini3; Gabriel Elias Dumke; ; Felipe Manfio Somavilla4; Samanta Luiza da Costa ${ }^{4}$
\end{abstract}

\section{Highlights}

The rate of node appearance ranges from 2.20 to 8.23 days node ${ }^{-1}$.

The final number of nodes varies from 2.20 to 17.20 .

The period of node emission ranges from 16.60 to 49.20 days.

\begin{abstract}
The aim of this study was to determine the rate of node appearance (RNA), the final number of nodes (FNN) and the period of node emission (PNE) in two buckwheat cultivars (Fagopyrum esculentum Moench) for different sowing dates, and to check variability in the RNA, FNN and PNE between the cultivars and sowing dates. The IPR91-Baili and IPR92-Altar cultivars were evaluated for 29 and 31 sowing dates from October to May in the 2017/2018 and 2018/2019 agricultural years respectively. In each experiment, a completely randomised design with five replications was used. The number of nodes (NN) on the main stem was counted twice a week in each plant (replication), from emission of the first node until the end of the cycle. The linear regression $(y=a+b x)$ of the number of nodes $(N N, y)$ was adjusted for each plant based on the number of days after emergence (DAE, $x$ ). The rate of node appearance (RNA), in days node ${ }^{-1}$, was determined from the inverse of the slope of the linear regression between NN and DAE (RNA $=1 / b$ ). The RNA was calculated for the period of node emission (PNE, in days), i.e. from emergence to emission of the last node. The final number of nodes (FNN) was counted at the end of node emission. Variability was found in the rate of node appearance (RNA), the final number of nodes (FNN) and the period of node emission (PNE) between the cultivars and sowing dates. The rate of node appearance ranges between 2.20 and 8.23 days node ${ }^{-1}$, the final number of nodes between 2.20 and 17.20, and the period of node emission between 16.60 and 49.20 days. Plants of the IPR91-Baili and IPR92-Altar cultivars show better vegetative development (lower RNA,

1 Prof., Universidade Federal de Santa Maria, UFSM, Santa Maria, RS, Brasil. E-mail: alberto.cargnelutti.filho@gmail.com

2 Discente do Curso de Doutorado do Programa de Pós-Graduação em Agronomia, UFSM, Santa Maria, RS, Brasil. E-mail: ismaelmmneu@hotmail.com

3 M.e em Agronomia, Programa de Pós-Graduação em Agronomia, UFSM, Santa Maria, RS, Brasil. E-mail: rvpezzini@ hotmail.com

4 Discentes do Curso de Graduação em Agronomia, UFSM, Santa Maria, RS, Brasil. E-mail: gabrieleliasdumke@gmail. com; felipe-somavilla@hotmail.com; samyldc09@hotmail.com

* Author for correspondence
\end{abstract}

Received: Apr. 10, 2020 - Approved: Oct. 08, 2020 
higher FNN and greater PNE) when sown in November, December, January and February, compared to those sown in October, March, April and May.

Key words: Vegetative development. Fagopyrum esculentum Moench. Final number of nodes. Period of node emission. Rate of node appearance.

\section{Resumo}

Os objetivos deste trabalho foram determinar a taxa de aparecimento de nós (TAN), o número final de nós (NFN) e o período de emissão de nós (PEN) em duas cultivares de trigo mourisco (Fagopyrum esculentum Moench) em datas de semeadura e verificar a variabilidade da TAN, do NFN e do PEN entre as cultivares e as datas de semeadura. As cultivares IPR91-Baili e IPR92-Altar foram avaliadas em 29 e 31 datas de semeadura, nos anos agrícolas 2017/2018 e 2018/2019, respectivamente, durante os meses de outubro a maio. Nos dois experimentos foi utilizado o delineamento inteiramente casualizado com cinco repetições. Em cada planta (repetição) foi contado o número de nós (NN) da haste principal, duas vezes por semana, a partir da emissão do primeiro nó até o final do ciclo. Para cada planta foi ajustada a regressão linear ( $y=a+b x)$ do número de nós (NN, y) em função do número de dias após a emergência (DAE, x). A taxa de aparecimento de nós (TAN), em dias nó ${ }^{-1}$, foi determinada pelo inverso do coeficiente angular da regressão linear entre o NN e o DAE (TAN=1/b). A TAN foi calculada para o período de emissão de nós (PEN, em dias), ou seja, entre a emergência até a emissão do último nó. O número final de nós (NFN) foi contabilizado na avaliação em que a planta cessou a emissão de nós. Há variabilidade da taxa de aparecimento de nós (TAN), do número final de nós (NFN) e do período de emissão de nós (PEN) entre as cultivares e as datas de semeadura. A taxa

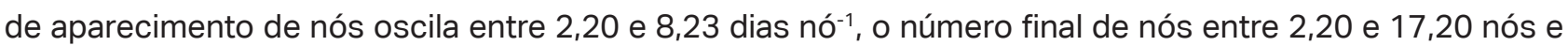
o período de emissão de nós entre 16,60 e 49,20 dias. As plantas das cultivares IPR91-Baili e IPR92-Altar, apresentam melhor desenvolvimento vegetativo (menor TAN, maior NFN e maior PEN) nas semeaduras nos meses de novembro, dezembro, janeiro e fevereiro em comparação com as semeaduras realizadas em outubro, março, abril e maio.

Palavras-chave: Desenvolvimento vegetativo. Fagopyrum esculentum Moench. Número final de nós. Período de emissão de nós. Taxa de aparecimento de nós.

\section{Introduction}

Buckwheat (Fagopyrum esculentum Moench) is an annual plant of family Polygonaceae, presenting fast growth, a short cycle, a high tolerance to acidity, and the ability to grow in low-fertility soils (Gonçalves et al., 2016). Studies with the crop show that its antioxidant and anti-inflammatory properties, and its nutritional content, enable its use in human nutrition and as a medicinal plant (Accame \& Ortega, 2019; Gonçalves et al.,
2016; Mikhailovich, 2019; Ratan \& Kothiyal, 2011; Yilmaz, Ayhan, \& Meriç, 2020). In addition, it can serve as forage for animal feed (Görgen et al., 2016), and as ground cover and a weed suppressor (Falquet, Gfeller, Pourcelot, Tschuy, \& Wirth, 2015; Pereira et al., 2017; Skora \& Campos, 2017). A comprehensive review of buckwheat has been made (Jacquemart, Cawoy, Kinet, Ledent, \& Quinet, 2012); the authors point out that characteristics such as a high sensitivity to abiotic factors, problems with pollen compatibility, sterility of female 
flower organs, and the lack of consistent flowering and grain maturation, need to be improved.

The buckwheat plant is sensitive to frost, heat, water deficit and photoperiod (Jacquemart et al., 2012), and genotypes have shown different development in different environments (Facho, Farhatullah, Khalil, Khan, \& Ali, 2016; Fesenko, Romanova, \& Fesenko, 2012; Jung et al., 2015). Therefore, varying the conditions of temperature, insolation, solar radiation, photoperiod and rainfall between sowing dates can influence vegetative development in the plant. It is therefore important to characterise genotypes and identify the environmental conditions that favour vegetative development, in order to obtain information as an aid to appropriate crop management.

The rate of node appearance represents the number of days necessary for the emission of one node and can be used to assess vegetative development (Baker \& Reddy, 2001). The smaller the number of days, the more accelerated vegetative development occurs. The final number of nodes and the period of node emission, between emergence and emission of the last node, are important in helping to characterise the vegetative development of the plants. Research involving aspects related to node emission and sowing dates has been carried out on buckwheat (Fesenko et al., 2012; Jung et al., 2015; Mikhailovich, 2019) and soybeans (Martins, Radons, Streck, Knies, \& Carlesso, 2011; Rocha et al., 2018), showing different plant responses to environmental variations, and highlighting the direct association between the number of nodes and leaf area, responsible for intercepting solar radiation and biomass accumulation (Xue, Weiss, \& Baenziger, 2004).
The number of nodes has been considered in studying the phenological and productive behaviour of buckwheat (Toledo \& Esteves, 2019).

In Brazil, only two cultivars are registered (IPR91-Baili and IPR92-Altar) (Ministério da Agricultura, Pecuária e Abastecimento [MAPA], 2020), and there is a lack of information on the crop. It is assumed that the buckwheat cultivars (IPR91-Baili and IPR92-Altar) have different responses in relation to node emission, and that it is possible to identify which sowing dates afford better vegetative development. As such, the aim of this study was to determine the rate of node appearance (RNA), the final number of nodes (FNN) and the period of node emission (PNE) in two buckwheat cultivars (Fagopyrum esculentum Moench) for different sowing dates, and to check variability in the RNA, FNN and PNE between the cultivars and sowing dates.

\section{Material and Methods}

Two experiments were conducted with buckwheat (Fagopyrum esculentum Moench) in an experimental area located at $29^{\circ} 42^{\prime} S$ and $53^{\circ} 49^{\prime} \mathrm{W}$, at an altitude of $95 \mathrm{~m}$. According to the Köppen classification, the climate is type Cfa, humid subtropical, with hot summers and no dry season (Alvares, Stape, Sentelhas, Gonçalves, \& Sparovek, 2013); the soil is a Distrophic Arenic Red Argisol (Santos et al., 2018). A physical and chemical analysis of the soil at a depth of $0-20 \mathrm{~cm}$ revealed: $\mathrm{pH}_{\mathrm{H} 2 \mathrm{O}}$ 1:1:5.5, Ca: $4.7 \mathrm{cmol}_{\mathrm{c}} \mathrm{dm}^{-3}, \mathrm{Mg}: 1.9 \mathrm{cmol}_{\mathrm{c}} \mathrm{dm}^{-}$ 3, Al: $0.0 \mathrm{cmol}_{\mathrm{c}} \mathrm{dm}^{-3}, \mathrm{H}+\mathrm{Al}: 4.4 \mathrm{cmol}_{\mathrm{c}} \mathrm{dm}^{-3}$; SMP index: 6.0 , organic matter: $2.3 \%$, clay content: 29.0\%, S: $1.5 \mathrm{mg} \mathrm{dm}^{-3}$, P (Mehlich): $32.8 \mathrm{mg} \mathrm{dm}^{-}$ ${ }^{3}, \mathrm{~K}: 0.532 \mathrm{cmol}_{\mathrm{c}} \mathrm{dm}^{-3}, \mathrm{CEC}_{\mathrm{pH} 7}: 11.6 \mathrm{cmol}_{\mathrm{c}} \mathrm{dm}^{-3}$, Cu: $2.2 \mathrm{mg} \mathrm{dm}^{-3}, \mathrm{Zn}: 1.01 \mathrm{mg} \mathrm{dm} \mathrm{m}^{-3}$, and $\mathrm{B}: 0.2$ 
$\mathrm{mg} \mathrm{dm}^{-3}$. These results were used to define the type of fertilisation (Comissão de Química e Fertilidade do Solo [CQFS], 2016).

Two buckwheat cultivars (IPR91Baili and IPR92-Altar) were evaluated for 29 and 31 sowing dates, during the 2017/2018 (experiment 1) and 2018/2019 (experiment 2) agricultural years respectively. A completely randomised design with five replications was used in a factorial scheme of 58 treatments in experiment 1 ( 2 cultivars $\times 29$ sowing dates) and 62 treatments in experiment 2 (2 cultivars $\times 31$ sowing dates). For each date, manual sowing was carried out in rows spaced $0.5 \mathrm{~m}$ apart at a density of $50 \mathrm{~kg} \mathrm{ha}^{-1}$, with a base fertilisation of $35 \mathrm{~kg} \mathrm{ha}^{-1} \mathrm{~N}, 135 \mathrm{~kg} \mathrm{ha}^{-1} \mathrm{P}_{2} \mathrm{O}_{5}$ and $135 \mathrm{~kg} \mathrm{ha}^{-1} \mathrm{~K}_{2} \mathrm{O}$. The plots comprised three rows, each $2 \mathrm{~m}$ in length $\left(3 \mathrm{~m}^{2}\right)$, with 85 seeds per metre of row.

Seedling emergence was determined daily by counting the number of plants visible above the ground, considering emergence as when $50 \%$ of the seedlings were visible. After emergence, five plants were randomly chosen per plot (five replications). For each plant (replication) from each treatment, the number of nodes (NN) on the main stem was counted. A node was considered visible when the leaf originating from that node was expanded, i.e. when the edges of the leaf were no longer touching. Therefore, 290 plants were evaluated in experiment 1 ( 5 plants per treatment $\times 58$ treatments) and 310 plants in experiment 2 (5 plants per treatment $\times 62$ treatments), giving a total of 600 plants. The counts were carried out twice weekly until the end of the plant cycle.

For each plant, the linear regression ( $y=a+b x)$ of the number of nodes ( NN, y) was adjusted based on the number of days after emergence $(D A E, x)$. The rate of node appearance (RNA), in days node-1, was determined by the inverse of the slope of the linear regression between NN and DAE $($ RNA $=1 / b)$. The RNA was calculated for the period of node emission, i.e. from emergence to emission of the last node. As an example, consider the data from a plant which was sown on $08 / 11 / 2017$, emergence was on $18 / 11 / 2017$ and the end of the cycle on $26 / 12 / 2017$. NN was evaluated on 23/11/2017, 27/11/2017, 30/11/2017, 04/12/2017, 07/12/2017, 11/12/2017, 14/12/2017, 18/12/2017, $21 / 12 / 2017$ and 26/12/2017, when the number of nodes was $1,2,3,4,5,5,6,8,10$ and 10 respectively. The plant issued the last node (10th node) on 21/12/2017 (9th evaluation), and on $26 / 12 / 2017$ (10th evaluation) it still had 10 nodes. Therefore, for the linear regression, the values of y were $1,2,3,4,5,5,6,8$ and 10 nodes, and for $x$ the values were $5,9,12,16,19,23,26$, 30 and 33 days after emergence respectively. The resultant linear regression was $y=-0.683$ $+0.290 x ; r^{2}=0.953$, so RNA $=1 / 0.290=3.450$ days node ${ }^{-1}$. The plant cycle was therefore 48 days (08/11/2017 to 26/12/2017), the period of node emission (PNE) was 38 days (18/11/2017 to $21 / 12 / 2017)$, and the final number of nodes (FNN) was 10.

The daily data for minimum (Tmin) and maximum (Tmax) air temperature, in ${ }^{\circ} \mathrm{C}$; insolation, in hours day ${ }^{-1}$; daily solar radiation, in $\mathrm{MJ} \mathrm{m} \mathrm{m}^{-2}$ day $^{-1}$; and rainfall, in $\mathrm{mm}$ were collected from the Weather Station of the 8th Meteorological District of the National Institute of Meteorology, located $70 \mathrm{~m}$ from the experimental area. The average daily air temperature (Tave), in ${ }^{\circ} \mathrm{C}$, was calculated from the expression: Tave $=(\operatorname{Tmin}+\operatorname{Tmax}) / 2$.

The data for the rate of node appearance, final number of nodes and period of node emission were submitted to analysis 
of variance and the mean values compared by Scott-Knott test at $5 \%$ probability. The statistical analysis was carried out with the aid of Microsoft Office Excel ${ }^{\bullet}$ and the Genes software (Cruz, 2016).

\section{Results and Discussion}

During the 2017/2018 agricultural year (experiment 1), the IPR91-Baili and IPR92-Altar buckwheat cultivars (Fagopyrum esculentum Moench) were evaluated from 01/11/2017 (first sowing date) until 14/062018 (final evaluation on the 29th sowing date), and during the 2018/2019 agricultural year (experiment 2), from 04/10/2018 (first sowing date) until $17 / 06 / 2019$ (final evaluation on the 31st sowing date). From October to June in each agricultural year, the monthly mean values for minimum (Tmin), maximum (Tmax) and average (Tave) air temperatures, in ${ }^{\circ} \mathrm{C}$, were higher in December, January and February, gradually reducing until June. The monthly averages for daily sunlight, in hours day ${ }^{-1}$, and daily solar radiation, in $\mathrm{MJ} \mathrm{m}^{-2}$ day $^{-1}$, were higher in November, December, January and February, with a gradual reduction towards October and June, except for January 2019, with 5.3 hours of insolation per day and solar radiation of 19.0 $\mathrm{MJ} \mathrm{m}^{-2}$ day $^{-1}$. The high volume of rainfall during that month $(266.1 \mathrm{~mm})$ is possibly the reason for the lower number of hours of sunlight and solar radiation (Table 1). These results are directly associated with the length of the day (photoperiod). On 1 October, the photoperiod at the experimental site was 12.32 hours, with a gradual and non-linear increase until 21
December, when it reached 13.91 hours. There was then a gradual and non-linear reduction until 21 June, reaching 10.09 hours (Figure 1).

The respective mean values for Tmin, Tmax and Tave were 16.1, 26.9 and 21.5 ${ }^{\circ} \mathrm{C}$ for the $2017 / 2018$ agricultural year, and 17.4, 27.4 and $22.4{ }^{\circ} \mathrm{C}$ for $2018 / 2019$. Mean daily insolation was 6.7 hours day ${ }^{-1}$ during the 2017/2018 agricultural year, and 6.3 hours day ${ }^{-1}$ during 2018/2019, which shows that on average, in experiment 1 the plants received 0.4 hours day ${ }^{-1}$ more sunlight. During the 2017/2018 agricultural year, the mean daily solar radiation was $17.7 \mathrm{MJ} \mathrm{m}^{-2}$ day 1 and in 2018/2019, it was 17.2 $\mathrm{MJ} \mathrm{m}^{-2}$ day $^{-1}$. Accumulated rainfall from October 2017 to June 2018 was $1,173.9 \mathrm{~mm}$ and from October 2018 to June 2019 it was $1,513.5 \mathrm{~mm}$. These values were similar to the climate normal for 1981-2010 (Table 1). Therefore, considering the same period (October to June) the plants in the $2017 / 2018$ agricultural year (experiment 1) were exposed to lower temperatures, greater insolation, more solar radiation and less rainfall in relation to the $2018 / 2019$ agricultural year (experiment 2). Such different environmental conditions between agricultural years can result in different plant responses for the rate of node appearance, the final number of nodes and the period of node emission. According to Jacquemart et al. (2012), buckwheat phenology and production mainly respond to three climate factors: temperature, rainfall and photoperiod. The authors also state that the plant is sensitive to frost, heat, water deficit and, for photosensitive varieties, an extended photoperiod. 
Table 1

Monthly mean minimum (Tmin), maximum (Tmax) and average (Tave) air temperature, in ${ }^{\circ} \mathrm{C}$, monthly mean daily insolation, in hours day-1, monthly mean daily solar radiation, in $\mathrm{MJ} \mathrm{m}^{-2}$ day $^{-1}$, total rainfall, in $\mathrm{mm}$, during the evaluation periods of the IPR91-Baili and IPR92-Altar buckwheat cultivars (Fagopyrum esculentum Moench), with the climate normal for 1981-2010

\begin{tabular}{|c|c|c|c|c|c|c|c|}
\hline Month & Year & $\operatorname{Tmin}\left({ }^{\circ} \mathrm{C}\right)$ & $\operatorname{Tmax}\left({ }^{\circ} \mathrm{C}\right)$ & Tave $\left({ }^{\circ} \mathrm{C}\right)$ & $\begin{array}{l}\text { Insolation } \\
\text { (hrs day }^{-1} \text { ) }\end{array}$ & $\begin{array}{c}\text { Radiation } \\
\left(\mathrm{MJ} \mathrm{m}^{-2} \text { day }^{-1}\right)\end{array}$ & $\begin{array}{c}\text { Rainfall } \\
(\mathrm{mm})\end{array}$ \\
\hline \multicolumn{8}{|c|}{$2017 / 2018$ agricultural year (experiment 1) } \\
\hline October ${ }^{(1)}$ & 2017 & 15.4 & 25.0 & 20.2 & 5.7 & 17.5 & 243.2 \\
\hline November & 2017 & 14.8 & 28.1 & 21.4 & 9.0 & 24.4 & 70.0 \\
\hline December & 2017 & 19.2 & 30.9 & 25.1 & 8.5 & 24.1 & 83.9 \\
\hline January & 2018 & 19.9 & 30.3 & 25.1 & 7.8 & 22.2 & 122.2 \\
\hline February & 2018 & 18.4 & 29.9 & 24.1 & 8.5 & 22.7 & 108.9 \\
\hline March & 2018 & 17.3 & 28.9 & 23.1 & 7.1 & 17.7 & 167.6 \\
\hline April & 2018 & 18.5 & 28.8 & 23.6 & 6.0 & 13.1 & 167.6 \\
\hline May & 2018 & 13.6 & 22.2 & 17.9 & 4.4 & 9.7 & 59.9 \\
\hline June & 2018 & 7.9 & 17.7 & 12.8 & 3.8 & 7.8 & 150.6 \\
\hline Mean & & 16.1 & 26.9 & 21.5 & 6.7 & 17.7 & 130.4 \\
\hline \multicolumn{8}{|c|}{$2018 / 2019$ agricultural year (experiment 2) } \\
\hline October & 2018 & 15.3 & 25.4 & 20.4 & 6.6 & 18.9 & 101.5 \\
\hline November & 2018 & 17.7 & 28.8 & 23.3 & 7.9 & 22.8 & 245.1 \\
\hline December & 2018 & 18.7 & 30.0 & 24.4 & 8.3 & 24.4 & 176.2 \\
\hline January & 2019 & 21.9 & 30.8 & 26.4 & 5.3 & 19.0 & 266.1 \\
\hline February & 2019 & 19.1 & 30.0 & 24.6 & 8.1 & 21.7 & 83.4 \\
\hline March & 2019 & 17.2 & 28.1 & 22.7 & 7.2 & 18.3 & 136.3 \\
\hline April & 2019 & 17.3 & 26.4 & 21.8 & 5.1 & 12.6 & 210.4 \\
\hline May & 2019 & 15.4 & 22.5 & 19.0 & 3.6 & 8.2 & 260.2 \\
\hline June & 2019 & 14.2 & 24.4 & 19.3 & 4.3 & 9.2 & 34.3 \\
\hline Mean & & 17.4 & 27.4 & 22.4 & 6.3 & 17.2 & 168.2 \\
\hline \multicolumn{8}{|c|}{ Climate normal for 1981-2010 } \\
\hline October & & 14.8 & 25.2 & 19.4 & 5.8 & - & 173.3 \\
\hline November & & 16.4 & 27.8 & 21.6 & 7.3 & - & 132.7 \\
\hline December & & 18.6 & 30.3 & 24.1 & 8.1 & - & 154.3 \\
\hline January & & 19.8 & 30.9 & 24.9 & 7.9 & - & 166.3 \\
\hline February & & 19.4 & 29.9 & 24.0 & 7.1 & - & 139.6 \\
\hline March & & 18.5 & 29.1 & 22.9 & 6.8 & - & 127.7 \\
\hline April & & 15.0 & 25.7 & 19.4 & 5.8 & - & 170.1 \\
\hline May & & 12.0 & 22.0 & 16.0 & 5.0 & - & 154.4 \\
\hline June & & 10.3 & 19.7 & 14.2 & 4.1 & - & 149.1 \\
\hline Mean & & 16.1 & 26.7 & 20.7 & 6.4 & & 151.9 \\
\hline
\end{tabular}

(1) In October 2017, no buckwheat was sown due to the high volume of rainfall ( $243.2 \mathrm{~mm})$; however, the data are shown in order to compare the two agricultural years (2017/2018 and 2018/2019) for the same period, i.e. from October to June. 


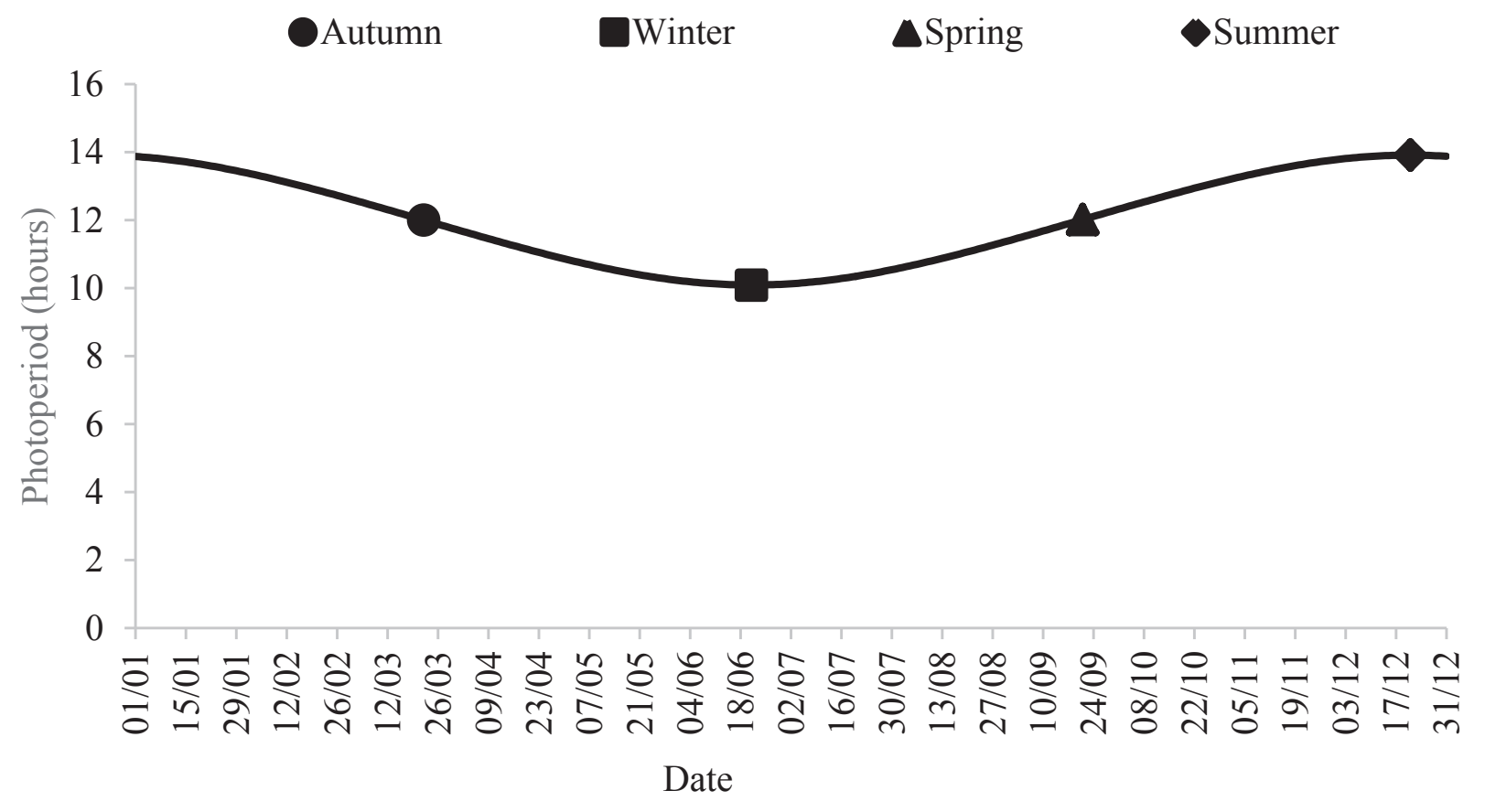

Figure 1. Photoperiod, in hours, from 01 January to 31 December showing the start of each season in the area of the experiments with the IPR91-Baili and IPR92-Altar buckwheat cultivars (Fagopyrum esculentum Moench).

The relationship between the number of nodes (NN, y) and the number of days after emergence $(\mathrm{DAE}, \mathrm{x})$ in the 600 buckwheat plants was linear, showing high coefficients of determination $\left(r^{2}\right)$, which ranged from 0.80 to 1.00 , with an average $r^{2}$ for the 600 estimates of 0.96 . It can be inferred from this that the rate of node appearance estimated by the method of linear regression $(y=a+b x)$ between $N N$ and DAE was applicable and reliable.

In the 2017/2018 agricultural year (experiment 1), using the F-test from the analysis of variance, it was found that there was no cultivar $\times$ sowing date interaction $(p>0.05)$ in relation to the rate of node appearance (RNA, days node-1), the final number of nodes (FNN) or the period of node emission ( $P N E$, in days) in buckwheat (Fagopyrum esculentum Moench). This means that the IPR91-Baili and IPR92-Altar cultivars showed similar responses for the 29 sowing dates. The main effect of the cultivars was not significant $(p>0.05)$, whereas that of the sowing dates was significant $(p \leq 0.05)$, inferring that the RNA, FNN and PNE vary between sowing dates. This makes it possible to investigate the dates that afford the best vegetative plant development.

Irrespective of sowing date, the mean RNA of the IPR91-Baili cultivar (3.19 days node1) did not differ from that of the IPR92-Altar cultivar (3.25 days node-1). This means that for the sowing carried out from 01/11/2017 to $16 / 05 / 2018$ the cultivars emitted an average of one node every 3.22 days (Table 
2). However, the RNA differed between sowing dates, ranging from 2.34 to 5.31 days node ${ }^{-1}$. Three groups of mean values were formed by the Scott-Knott test, with the highest RNA values concentrated on the later sowing dates, which suggests less plant development, as they took longer for node emission. For the 29 sowing dates, the IPR91-Baili and IPR92-Altar cultivars emitted an average of 10.39 nodes per plant, showing no difference from each other. Between the sowing dates, the FNN ranged from 2.20 to 15.70 nodes and seven groups of mean values were formed. Higher values for FNN were observed for plants sown in December, with a gradual reduction towards November and May. The mean value for PNE in the IPR91-Baili and IPR92-Altar cultivars was the same, i.e. the time between emergence and emission of the last node was 35.2 days. Between the sowing dates, the PNE ranged from 21 to 47.7 days and six groups of mean values were formed. The PNE was longer in December, with a gradual reduction towards November and May. 


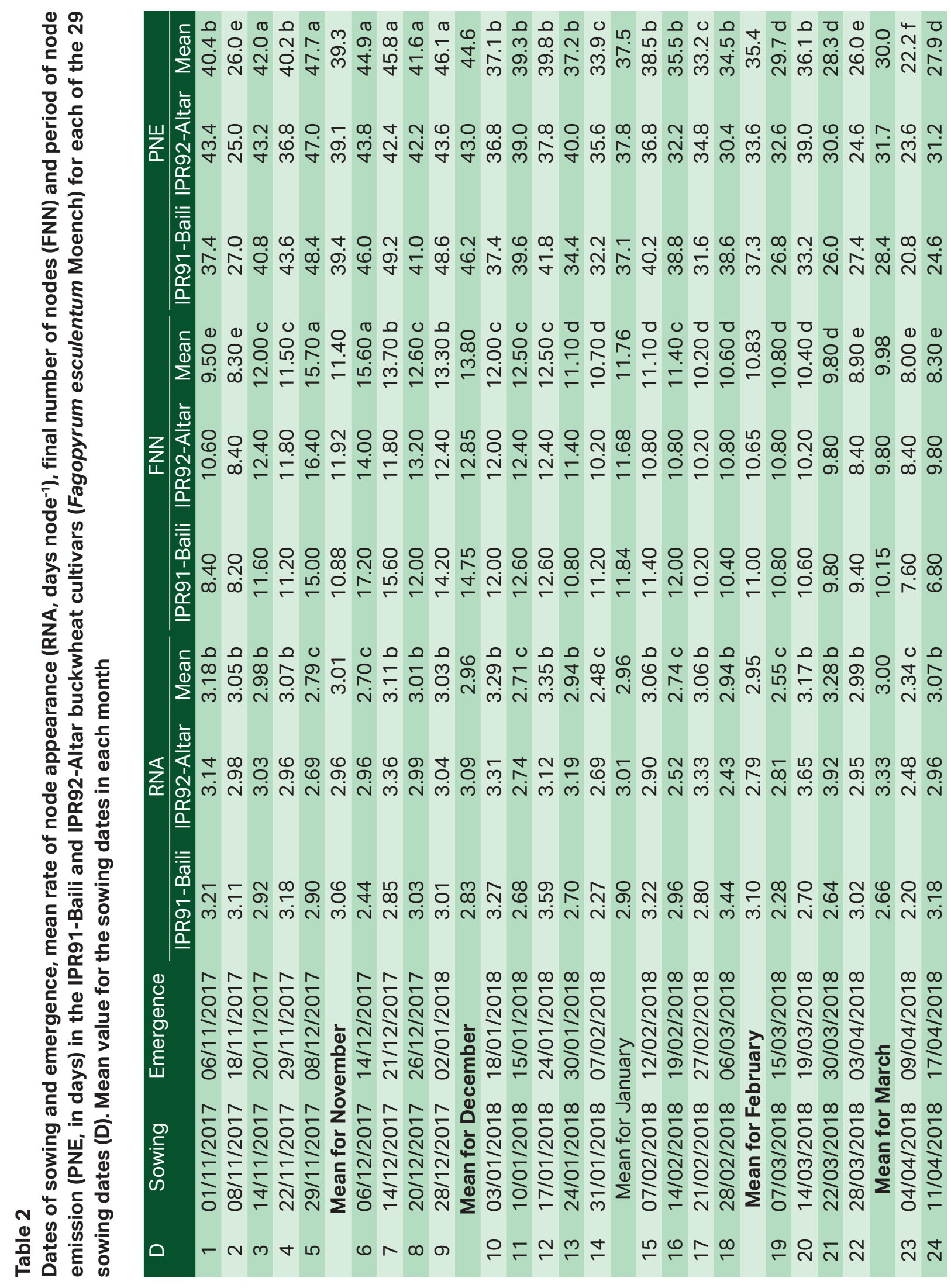




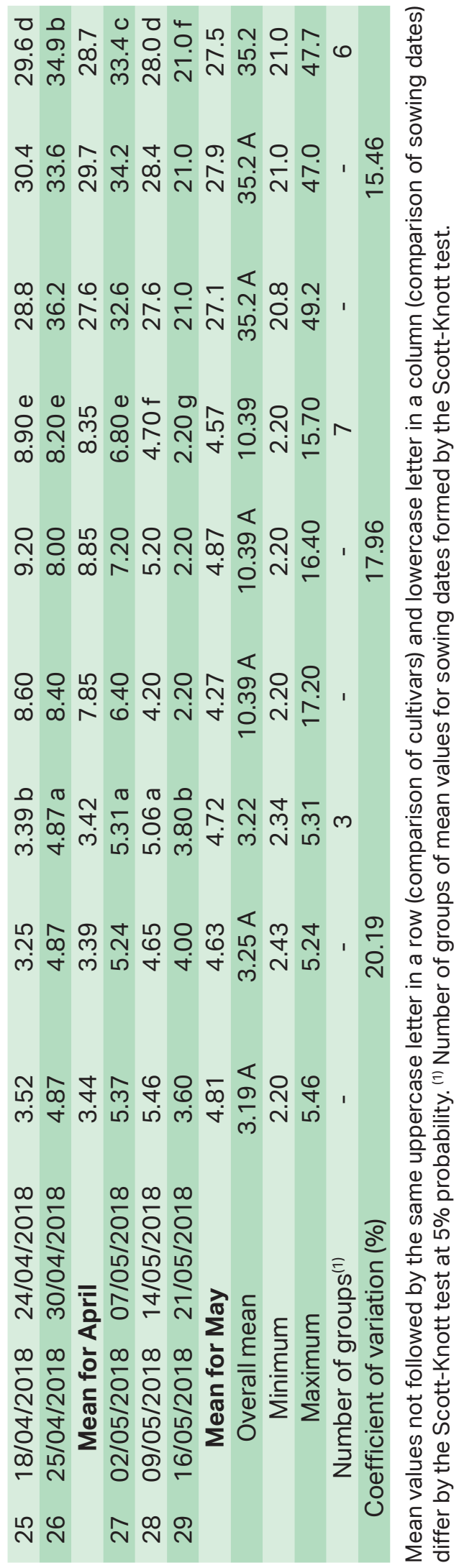


During the 2017/2018 agricultural year, it was generally found that the values for RNA remained similar up to the sowing carried out in February, and gradually increased from the sowings carried out in March onwards. Higher values for FNN and PNE were seen in December, gradually decreasing towards November and May. These results suggest better vegetative development of the IPR91Baili and IPR92-Altar cultivars for sowings carried out in November, December, January and February. For these months, the mean values for RNA were respectively 3.01, 2.96, 2.96 and 2.95 days node-1, for FNN 11.40, 13.80, 11.76, 10.83 nodes, and for PNE 39.3, 44.6, 37.5 and 35.4 days (Table 2). Therefore, from November to February, the plants spent more time emitting nodes (greater PNE) and at a higher rate (lower RNA), consequently issuing more nodes (higher FNN). In March, April and May the mean values for RNA were respectively $3.00,3.42$ and 4.72 days node1, for FNN 9.98, 8.35 and 4.57 nodes, and for PNE 30.0, 28.7 and 27.5 days. This means a gradual reduction in vegetative development for plants sown in March, April and May, i.e. there was a gradual increase in RNA and a gradual reduction in FNN and PNE. This slower plant development in March, April and May is possibly associated with the gradual reduction in the minimum (Tmin), maximum (Tmax) and average (Tave) air temperature, insolation, radiation and photoperiod (Table 1 and Figure 1). It can therefore be inferred that as the sowing date advanced there was a reduction in plant development. A similar result was seen by Martins et al. (2011) and Rocha et al. (2018), who found a reduction in the final number of nodes on the main stem of soybeans when sown late.

In the 2018/2019 agricultural year (experiment 2), the F-test in the analysis of variance revealed an interaction between cultivar $\times$ sowing date $(p \leq 0.05)$ in relation to the RNA, FNN and PNE. This means that the IPR91-Baili and IPR92-Altar cultivars showed different responses for the sowing dates, inferring variability in the RNA, FNN and PNE between cultivars and between sowing dates; however, greater variation was seen between the sowing dates within each cultivar than between cultivars within each sowing date. An interaction between 20 buckwheat genotypes and four environments has been found for the number of days to flowering, number of days to maturation, plant height and 1000 -grain weight (Facho et al., 2016).

Only on sowing date 02/05/2019 was the RNA of IPR92-Altar (8.23 days node-1) higher than that of IPR91-Baili (5.01 days node$1) ;$ on the remaining sowing dates there was no difference between cultivars. When comparing sowing dates within each cultivar, three and four groups of mean RNA values were formed for IPR91-Baili and IPR92-Altar respectively. The RNA of the IPR91-Baili cultivar varied between 3.02 and 7.31 days node ${ }^{-1}$, and of the IPR92-Altar cultivar, between 2.72 and 8.23 days node-1 (Table 3); albeit, with the presence of the interaction, it was seen that RNA values were lower from October to February and then gradually increased for sowings carried out in March, April and May. This means that with the delay in sowing date, the plants took longer to emit nodes from March onwards. 


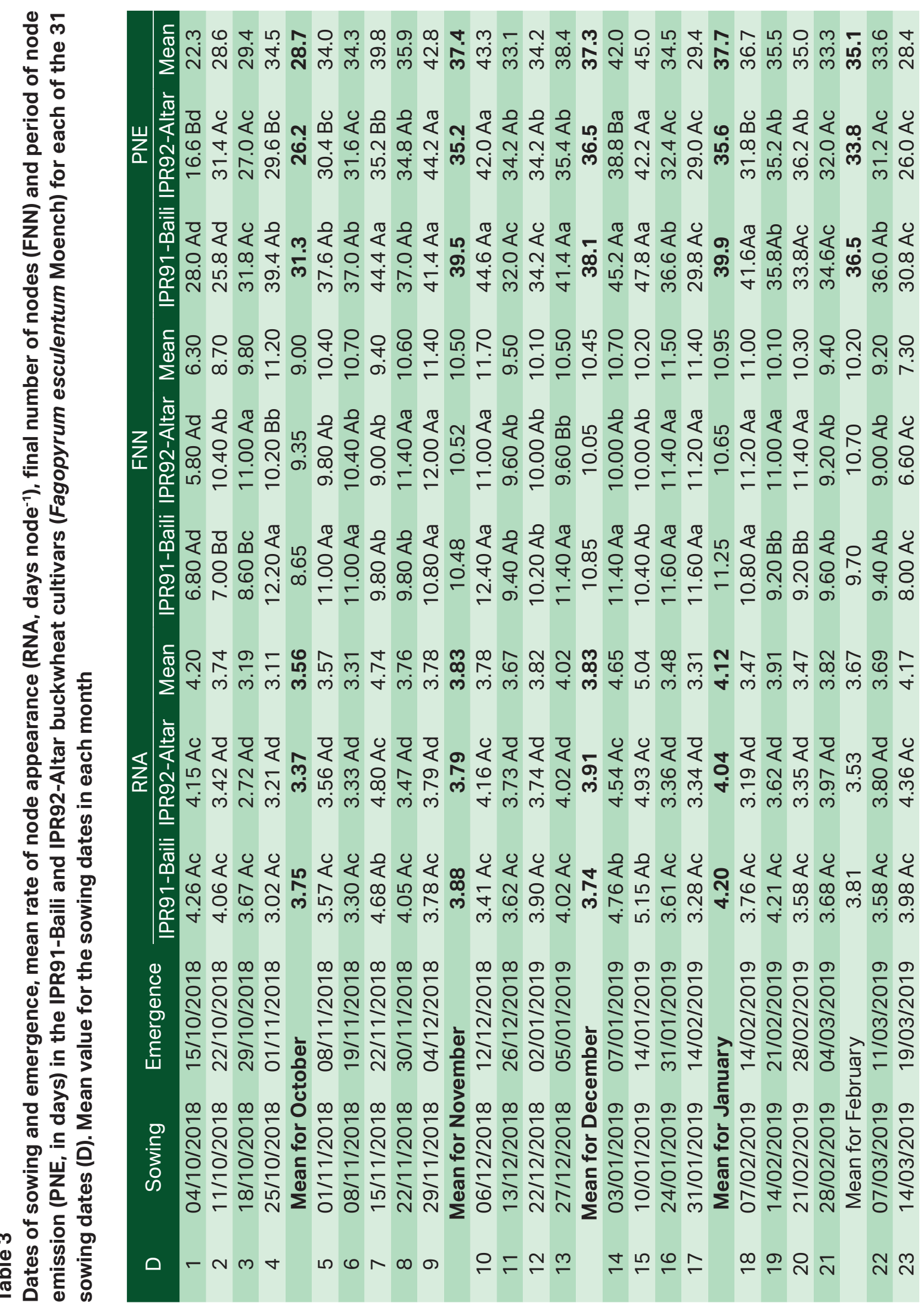


$\infty$ m

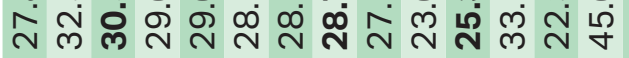

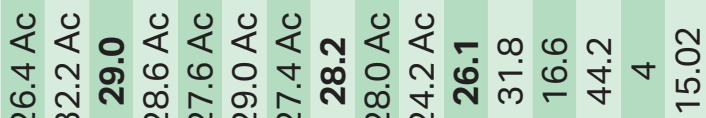

กे กั

กั กิ

定定

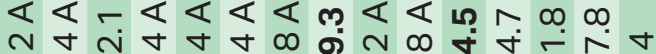

กั

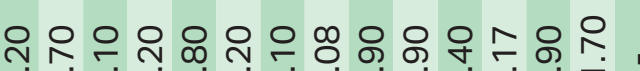

ヘ $\infty \infty$ ம

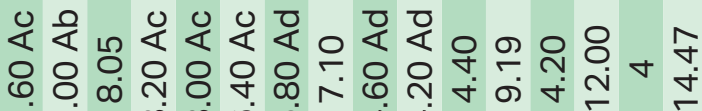

กั $\infty 0^{\circ}$

ㄷํㅇ 옫

䨔

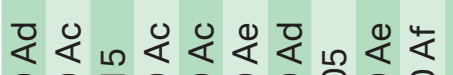

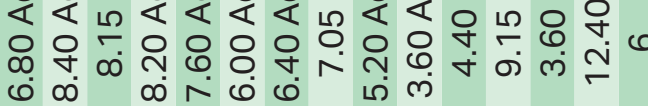

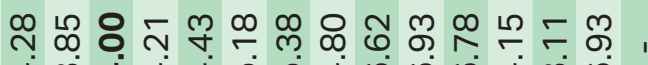

オ

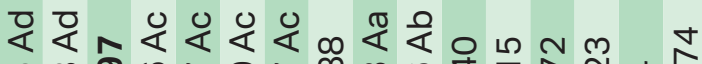

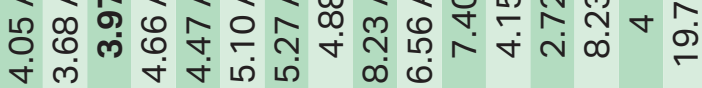

选定

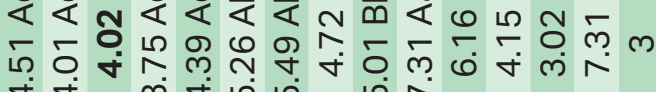

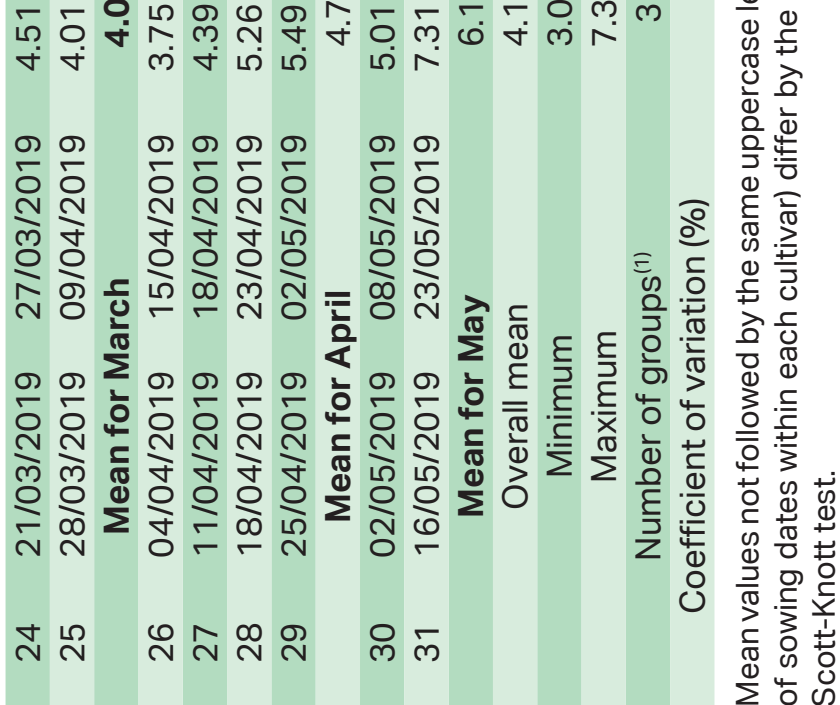


There was a difference between cultivars in relation to the FNN for six sowing dates. On dates 2, 3, 19 and 20, the IPR92-Altar cultivar emitted more nodes than did IPR91Baili, whereas on dates 4 and 13 the opposite occurred, showing cultivar responses in opposite directions (complex interaction). When comparing sowing dates within each cultivar, six and four groups of mean FNN values were formed for the IPR91-Baili and IPR92Altar cultivars respectively. The FNN varied between 3.60 and 12.40 nodes for IPR91-Baili and between 4.20 and 12.00 nodes for IPR92Altar (Table 3). Again, despite the interaction, higher values for FNN were seen in November, December, January and February compared to October, March, April and May, with a gradual reduction towards October and May. Variability in the number of nodes between buckwheat cultivars and between sowing dates was found by Jung et al. (2015) in Central Korea. In Brazil, in the same place as the present experiments, Rocha et al. (2018) found that the final number of nodes in soybeans varies with the photoperiod to which the plant is exposed during the vegetative phase (emergence until the appearance of the last node) and differs between cultivars, with the lowest values seen in early sowings (September) and late sowings (January and February).

For six sowing dates $(1,4,5,7,14$ and 18) the IPR91-Baili cultivar presented a greater PNE than did IPR92-Altar, which shows that the differing responses of the cultivars were in the same direction (simple interaction). Between sowing dates, the PNE of the IPR91-Baili cultivar ranged from 21.8 to 47.8 days, and of IPR92Altar from 16.6 to 44.2 days, with four groups of mean values being formed when comparing the dates within each cultivar (Table 3). The values for PNE were higher during November,
December, January and February, showing a gradual reduction towards October and May.

The IPR91-Baili and IPR92-Altar cultivars showed better development during November, December, January and February, i.e. the mean values for RNA were respectively 3.83, 3.83, 4.12 and 3.67 days node ${ }^{-1}$, for FNN $10.50,10.45,10.95$ and 10.20 nodes, and for PNE 37.4, 37.3, 37.7 and 35.1 days. In October, March, April and May, the cultivars showed less development, i.e. the mean values for RNA were respectively $3.56,4.00,4.80$ and 6.78 days node- ${ }^{-1}$, for FNN 9.00, 8.10, 7.08 and 4.40 nodes, and for PNE 28.7, 30.5, 28.7 and 25.3 days (Table 3). This means that during October, March, April and May the plants took longer to emit nodes, continued to emit nodes for a shorter period and, as a result, emitted less nodes. During these months, heat availability, insolation, radiation and photoperiod were lower, and are possibly the cause of the slower vegetative development (Table 1 and Figure 1).

During the 2017/2018 agricultural year (experiment 1) the mean values for RNA, FNN and PNE were 3.22 days node ${ }^{-1}, 10.39$ nodes and 35.2 days (Table 2). Whereas for $2018 / 2019$ (experiment 2), the mean values were 4.15 days node ${ }^{-1}, 9.17$ nodes and 33.2 days (Table 3 ). The lower temperature, greater insolation, higher solar radiation and lower rainfall during the 2017/2018 agricultural year (experiment 1) may have contributed to the better vegetative development of the plants. Despite this slight difference between agricultural years, cultivar response for sowing date within each agricultural year was similar. Better vegetative plant development was seen in November, December, January and February. During these months the plants emitted nodes more quickly (lower RNA), spent more time on node emission (greater PNE) and consequently 
emitted more nodes (greater FNN). Vegetative development in the plants gradually decreased towards October and May, i.e. the plants spent less time emitting nodes (smaller PNE) and at a lower rate of emission (higher RNA), which resulted in a smaller final number of nodes (lower FNN). As such, it can be inferred that the IPR91-Baili and IPR92-Altar cultivars showed better performance in relation to node emission for sowings in November, December, January and February.

\section{Conclusions}

For buckwheat, variability exists between cultivars and sowing dates in the rate of node appearance (RNA), the final number of nodes (FNN) and the period of node emission (PNE). The rate of node appearance varies between 2.20 and 8.23 days node $^{-1}$, the final number of nodes between 2.20 and 17.20 nodes, and the period of node emission between 16.60 and 49.20 days. Plants of the IPR91-Baili and IPR92-Altar cultivars display better vegetative development (lower RNA higher FNN and greater PNE) for sowing dates in November, December, January and February compared to sowing dates in October, March, April and May.

\section{Acknowledgements}

The authors wish to thank the Conselho Nacional de Desenvolvimento Científico e Tecnológico (CNPq - Processes 401045/20161 and 304652/2017-2) and the Coordenação de Aperfeiçoamento de Pessoal de Nível Superior (CAPES) for granting scholarships to the authors. The authors would also like to thank the Fundação de Amparo à Pesquisa do
Estado do Rio Grande do Sul (FAPERGS) for the grant of a scientific initiation scholarship. Thanks are also due to the scholarship students and volunteers for their assistance in collecting the data.

\section{References}

Accame, M. E. C., \& Ortega, T. (2019). Trigo sarraceno. Panorama Actual del Medicamento, 43(420), 133-136.

Alvares, C. A., Stape, J. L., Sentelhas, P. C., Gonçalves, J. L. M., \& Sparovek, G. (2013). Köppen's climate classification map for Brazil. Meteorologische Zeitschrift, 22(6), 711-728. doi: 10.1127/0941-2948/ 2013/0507

Baker, J. T., \& Reddy, V. R. (2001). Temperature effects on phenological development and yield of muskmelon. Annals of Botany, 87(5), 605-613. doi: 10.1006/ anbo.2001.1381

Comissão de Química e Fertilidade do Solo (2016). Manual de calagem e adubação para os Estados de Rio Grande do Sul e de Santa Catarina (11a ed.). Viçosa, MG: Sociedade Brasileira de Ciência do Solo.

Cruz, C. D. (2016). Genes Software - extended and integrated with the $\mathrm{R}$, Matlab and Selegen. Acta Scientiarum Agronomy, 38(4), 547-552. doi: 10.4025/actasciagron. v38i4.32629

Facho, Z. H., Farhatullah, Khalil, I. H., Khan, N. U., \& Ali, S. (2016). Morphological characterization and estimation of genotype $\times$ environment interaction of indigenous buckwheat germplasm collected from Gilgit Baltistan Pakistan. Pakistan Journal of Botany, 48(6), 23912398. 
Falquet, B., Gfeller, A., Pourcelot, M., Tschuy, F., \& Wirth, J. (2015). Weed suppression by common buckwheat: a review. Environmental Control in Biology, 53(1), 1-6. doi: 10.2525/ecb.53.1

Fesenko, A., Romanova, O., \& Fesenko, N. N. (2012). Peculiarities of common buckwheat adaptation to growing conditions. The European Journal of Plant Science and Biotechnology, 6(2), 75-79.

Gonçalves, F. M. F., Debiage, R. R., Silva, R. M. G., Porto, P. P., Yoshihara, E., \& Peixoto, E. C. T. M. (2016). Fagopyrum esculentum Moench: a crop with many purposes in agriculture and human nutrition. African Journal of Agricultural Research, 11(12), 983-989. doi: 10.5897/AJAR2015.10747

Görgen, A. V., Cabral, S. L. S., Fo., Leite, G. G., Spehar, C. R., Diogo, J. M. S., \& Ferreira, D. B. (2016). Produtividade e qualidade da forragem de trigo-mourisco (Fagopyrum esculentum Moench) e de milheto (Pennisetum glaucum (L.) R.BR). Revista Brasileira de Saúde e Produção Animal, 17(4), 599-607. doi: 10.1590/S151999402016000400004

Jacquemart, A. L., Cawoy, V., Kinet, J. M., Ledent, J. F., \& Quinet, M. (2012). Is buckwheat (Fagopyrum esculentum Moench) still a valuable crop today? The European Journal of Plant Science and Biotechnology, 6(2), 1-10.

Jung, G. H., Kim, S. L., Kim, M. J., Kim, S. K., Park, J. H., Kim, C. G., \& Heu, S. (2015). Effect of sowing time on buckwheat (Fagopyrum esculentum Moench) growth and yield in Central Korea. Journal of Crop Science and Biotechnology, 18(4), 285-291. doi: 10.1007/s 12892-015-0117-6

Martins, J. D., Radons, S. Z., Streck, N. A., Knies, A. E., \& Carlesso, R. (2011). Plastocrono e número final de nós de cultivares de soja em função da época de semeadura. Ciência Rural, 41(6), 954-959. doi: 10. 1590/S0103-84782011005000064

Mikhailovich, G. N. (2019). Las bases para cultivo de alforfón (trigo sarraceno) Fagopyrum esculentum en Centroamérica. Revista Científica Tecnológica, 2(1), 8-13.

Ministério da Agricultura, Pecuária e Abastecimento (2020). Registro nacional de cultivares. Recuperado de http:// sistemas.agricultura.gov.br/snpc/ cultivarweb/cultivares_registradas.php

Pereira, A. P., Schoffel, A., Koefender, J., Camera, J. N., Golle, D. P.,... Horn, R. C. (2017). Ciclagem de nutrientes por plantas de cobertura de verão. Revista de Ciências Agrárias, 40(4), 799-807. doi: 10.190 84/ RCA17065

Ratan, P., \& Kothiyal, P. (2011). Fagopyrum esculentum Moench (common buckwheat) edible plant of Himalayas: A Review. Asian Journal of Pharmacy and Life Science, 1(4), 426-442.

Rocha, T. S. M., Streck, N. A., Bexaira, K. P., Ribas, G. G., Tagliapietra, E. L., Winck, J. E. M.,... Zanon, A. J. (2018). Plastocrono e número final de nós de cultivares de soja em diferentes épocas de semeadura Agrometeoros, 26(1), 247-256. doi: 10.31062/agrom.v26i1.26346

Santos, H. G., Jacomine, P. K. T., Anjos, L. H. C., Oliveira, V. A., Lumbreras, J. F., Coelho, M. R.,... Cunha, T. J. F. (2018). Sistema brasileiro de classificação de solos (5a ed.). Brasília: EMBRAPA.

Skora, F., Neto, \& Campos, A. C. (2017). Plantas de cobertura antecedendo a cultura de trigo. Scientia Agraria Paranaensis, 16(4), 463-467. doi: 10.18188/1983-1471/sap. v16n4p463-467 
Toledo, R., \& Esteves, N. (2019). Estudio del comportamiento fenológico y productivo de trigo sarraceno (Fagopyrum esculentum Moench), en la zona centro de Córdoba, Argentina. Nexo Agropecuário, 7(2), 6-10.

Xue, Q., Weiss, A., \& Baenziger, P. S. (2004). Predicting leaf appearance in fieldgrown winter wheat: Evaluating linear and non-linear models. Ecological Modeling, 175(3), 261-270. doi: 10.1016/j. ecolmodel.2003.10.018
Yilmaz, H. Ö., Ayhan, N. Y., \& Meriç, Ç. S. (2020). Buckwheat: a useful food and its effects on human health. Current Nutrition \& Food Science, 16(1), 29-34. doi: 10.2174/15734 01314666180910140021 
